\title{
Comparison of Effects of Teaching English to Thai Undergraduate Teacher-Students through Cross-Curricular Thematic Instruction Program Based on Multiple Intelligence Theory and Conventional Instruction
}

\author{
Saowalak Rattanavich ${ }^{1}$ \\ ${ }^{1}$ School of Education, Srinakharinwirot University, Bangkok, Thailand \\ Correspondence: Saowalak Rattanavich, School of Education, Srinakharinwirot University, Bangkok, Thailand. \\ Tel: 66-81-812-4862. E-mail: s_rattanavich@hotmail.com
}

Received: May 18, 2013 Accepted: June 19, 2013 Online Published: August 15, 2013

doi:10.5539/elt.v6n9p1 URL: http://dx.doi.org/10.5539/elt.v6n9p1

The research is financed by Research Development Fund of the School of Education, Srinakharinwirot University.

\begin{abstract}
This study is aimed at comparing the effects of teaching English to Thai undergraduate teacher-students through cross-curricular thematic instruction program based on multiple intelligence theory and through conventional instruction. Two experimental groups, which utilized Randomized True Control Group-Pretest-posttest Time Series Design and statistical data analysis using MANOVA with repeated measures, $t$-test for independent samples, basic statistical analysis and figures, showed significantly higher development in English performance (reading, listening-speaking and writing), expressed significantly positive opinions at a much higher level on the learning program, and identified more experiences in using each and every aspect of multiple intelligences than what the two control groups did. The results thus show that prospective teachers whose English language performance was enhanced with integrated content areas can benefit their students for learning English across the curriculum.
\end{abstract}

Keywords: cross-curricular thematic instruction, multiple intelligence theory, conventional instruction

\section{Introduction}

\subsection{Background and Description of Problem}

According to the report of National Testing Bureau in Thailand (2010), the average scores of Thai students at primary and secondary school levels, during the past few years, were below the standard level of about $50 \%$ in English as well as in other subjects. Even though the Ministry of Education in Thailand has been implementing the national educational strategic plan according to the Asean Declaration to improve the process of teaching English to Thai students, there has been little improvement. This is mainly because most Thai English teachers are poor both in spoken and written English. They speak mostly Thai in classes using grammar translation methods and other teacher- centered approach. Although the Ministry of Education fully supports the training of teachers in current teaching trends following student-centered approach and other active learning programs, the English teachers find it difficult to adopt the new approach of teaching techniques, because they lack the communication skills required. In addition, the teachers fail to provide students sufficient opportunities in integrating other subject matters across the curriculum to enable them to acquire well-rounded knowledge of English including vocabulary, idioms, and expressions that can be used in different contexts. The students are poor in their English communication skills because they do not get enough exposure to the variety of learning settings, especially those relevant to today's on-line world of new technology. There is thus an urgent need for conducting an effective English teaching program to undergraduate teacher-students who will soon start teaching Thai students in both primary and secondary schools around the country. This would enable Thai students to improve their communication skills and knowledge, besides inducing them in self-motivation to improve their English that will eventually become their life-long learning experience (Office of the Education Council, 
Ministry of Education, 2008).

\subsection{Objectives of the Study}

1) To compare the improvement achieved in English performance (listening-speaking, reading, and writing) by teacher-students taught through the program of cross-curriculum thematic instruction based on multiple intelligence theory with that achieved through conventional instruction.

2) To compare the teacher-students' opinion on learning through the program of cross-curriculum thematic instruction based on multiple intelligence theory with that through the program of conventional instruction.

3) To compare the teacher-students' experience of using multiple intelligences through the program of cross curriculum thematic instruction based on multiple intelligence theory with that of learning through conventional instruction.

\section{Literature Review}

\subsection{Language Learning Development Theory}

For any individual, the core process in developing any language consists of understanding the meaning or sense it conveys in different contexts of its usage. Whenever a language activity is conducted by any speaker or writer, the process of making sense will be performed by that speaker or writer himself or herself. He or she will interpret the meaning from the spoken voices or from the written symbols or even from the body language or facial expressions. Language is, therefore, a system comprising meanings, words, sounds, grammar, and symbols. The text of communication can be either a spoken or a written language, conveyed by an individual to another person or a group of persons. The text can be short or long, and formal or informal, depending on the context in which the language is used as the background of knowledge that enables one to clearly understand the meaning conveyed by one to another. To facilitate effective communication, depending on the contexts and cultures, the language register comprises three components: language activities, relationship of language users, and the mode of language use (spoken, written or body language, such as facial expressions or gestures.) (Halliday, 1978; Sebeok, 1991; Walker, 1994; Christie, 1994). Learning of the language is, therefore, related to personal practices and decisions of when and why to use it. Language and thought are thus interwoven in communication (Goodman, 1986: 26-28). Understanding the text types or genres in different contexts can help learners, especially second language or foreign language learners, to learn better schematic structure or text organization and linguistic features of the spoken and written texts. Genres in different contexts of language use can help students learn English as a second or foreign language in a sample format of language organization for different purposes for communication. In addition, learners can learn better the use of language elements in a naturally integrated way covering contextual meanings, different types of text structure, functional grammatical points, and idiomatic words or sentences that are frequently used in different language situations (Christie, 2005).

\subsection{Cross Curricular Thematic Instruction}

Developed from the concept of "Thematic Instruction", the teaching method that provides students opportunity to explore wider areas of study on a specific theme is the "Cross-Curricular Thematic Instruction". It allows students to integrate content and skills from multiple content areas into one cohesive learning experience. Through the process of teaching, the students can experience their school subjects as connected and interrelated, rather than isolated and fragmented. The learning activities are designed around topics of themes, as also across numerous areas of students' critical thinking process with different styles of learning and teaching. This instructional approach in the language class or learning of literacy enables the students to integrate their language skills in listening-speaking, reading and writing, as well as in learning other language components such as genres, idioms, expressions, etc. Planning of the lesson includes four main principles: 1) selecting the theme that can provide an easy link to other relevant and interesting topics; 2) choosing a key concept for instruction by selecting tasks that encourage students to investigate, speculate, problem-solve, and discuss or ask questions, which in turn enable them to explore other relevant topics of interest; 3 ) identifying skills and strategies to be taught through structured and carefully planned mini-lessons or interactive lessons; and 4) identifying appropriate resources for students that help them in further learning (Kovalik,1994; Vogt, 1994; http://www.funderstanding.com).

Through the cross-curricular thematic instruction, the teacher can use different learning styles and different learning approaches that are appropriate for different types of lessons, such as cooperative learning, inquiry learning, problem-based learning, research-based learning, project-based learning, etc. Through this, students can get better opportunities to evaluate themselves frequently from their own language activity involvement, both inside and outside the class. 


\subsection{Multiple Intelligence Theory}

The Theory of Multiple Intelligences, proposed by Howard Gardner (1983) in his book, Frames of Mind, states that intelligences are languages which are spoken by all people and are influenced, in part, by cultures in which people are born. Intelligences are life-time tools for learning, problem solving, and creating. Gardner defined intelligence as the ability to solve problem that one encounters in real life, the ability to generate new problems for solving, and the ability to make something or offer a service that is considered valuable in one's culture. As an educational researcher and psychologist, he emphasized the integral concept that all learners can learn through communication by listening, thinking, looking, moving, and working independently or in group. Fundamentally, Gardner's eight intelligences include the following: 1) linguistic intelligence consisting of the ability to think in words and to use language to express and appreciate complex meanings; 2) logical-mathematical intelligence consisting of the ability to calculate, quantify, consider propositions and hypotheses, and to carry out complex mathematical operations; 3) visual/spatial intelligence instilling the capacity to think in three-dimensional ways as do sailors, pilots, sculptors, painters and architects, to perceive external and internal imagery, to recreate, transform or modify images, to navigate oneself and objects through space, and to reproduce or decode graphic information; 4) bodily kinesthetic intelligence consisting of the ability to manipulate objects and fine-tune physical skills; 5) musical intelligence instilling the sensitivity to pitch, melody, rhythm, and tone; 6) interpersonal intelligence consisting of the capacity to understand and interact effectively with others; 7) intrapersonal intelligence consisting of the ability to construct an accurate perception of oneself and to use such knowledge in planning and directing one's life; and 8) naturalist intelligence consisting of observing patterns in nature, identifying and classifying objects, and understanding natural and human-made systems (Gardner, 1983, 1993; Campbell, L; Campbell, B; and Dickinson, D., 2004).

Multiple intelligences can be used as a tool to identify the learner's strong points in learning and to help the learner realize his or her strong and weak points in learning, while the teacher is able to integrate other content areas in the learning program, such as Arts, Music, Physical Education, Cultural Studies, etc. The Theory of Multiple Intelligences is an effective practical approach in developing curriculums or learning units, especially when it is applied to all learning activities to cover all the eight aspects of multiple intelligences that are relevant to learner's interest, attitude, and need. Using multiple intelligences in learning activities affects learner's inner motivation and stimulates the learner to practice autonomous learning (Lee, 2007; Starnes, 2007; Vaiou, 2010; BaŞ \& Beyhan, 2010). Various research studies in different countries on using multiple intelligences in integrated language learning programs with different content areas showed that the results are positive in students' language performance (Summerville, 1984; Drury, 1994; Drake, 2001; Chen, 2005). Educational researchers like Stephens (2007) and Kovalik (1994) strongly recommend that the teacher be able to help students memorize a variety of information and explore new knowledge by encouraging them to integrate the theory of multiple intelligences with cross-curriculum thematic instruction.

\subsection{The Program of Teaching English Using Cross-Curricular Thematic Instruction Based on Multiple Intelligence Theory versus Conventional Instruction}

As all the eight aspects of multiple intelligences can be adapted to design an effective activity program in learning, the teacher can open several windows of opportunity for students to use their potential in learning according to their interests and aptitudes and can enable the teacher to motivate and integrate more effectively language teaching across the curriculum through different activities, related to students' needs. By this approach, students can experience a broader vision of learning and can more actively practice the language used in different contexts and cultures. Through multiple intelligence activities, both the teacher and the student can evaluate their own strengths and weaknesses in teaching and learning which help them in finding better solutions to improving learning of English as well as learning other content areas in the curriculum around any special topic as a theme in each learning unit, based mainly on active language practices through different intelligences. Through self-initiated academic experiences, students enrich their content while learning to be autonomous learners, thinkers, and creators. As language and thought are interwoven, learning the use of their higher-level of thinking skills throughout the unit is doubtlessly beneficial to all types of students. They can eventually generalize what they learn, provide examples, connect the content to their personal experiences, and apply their knowledge to new situations.

Developing the program of teaching English to undergraduate teacher-students, the prospective teachers after graduation, through cross-curriculum thematic instruction based on multiple intelligence theory, can prove that the improvement in teacher-students' English language performance is much more as compared to the performance achieved through conventional instruction using student-centered approach. For this comparative investigation, students' attitudes to learning through teaching programs, as also their multiple intelligence 
activity experiences in English classes of both instructional programs were considered to ascertain which English program and integrated curriculum or other pre-in-service teacher program would be more beneficial.

\subsection{Conceptual Framework of the Study}

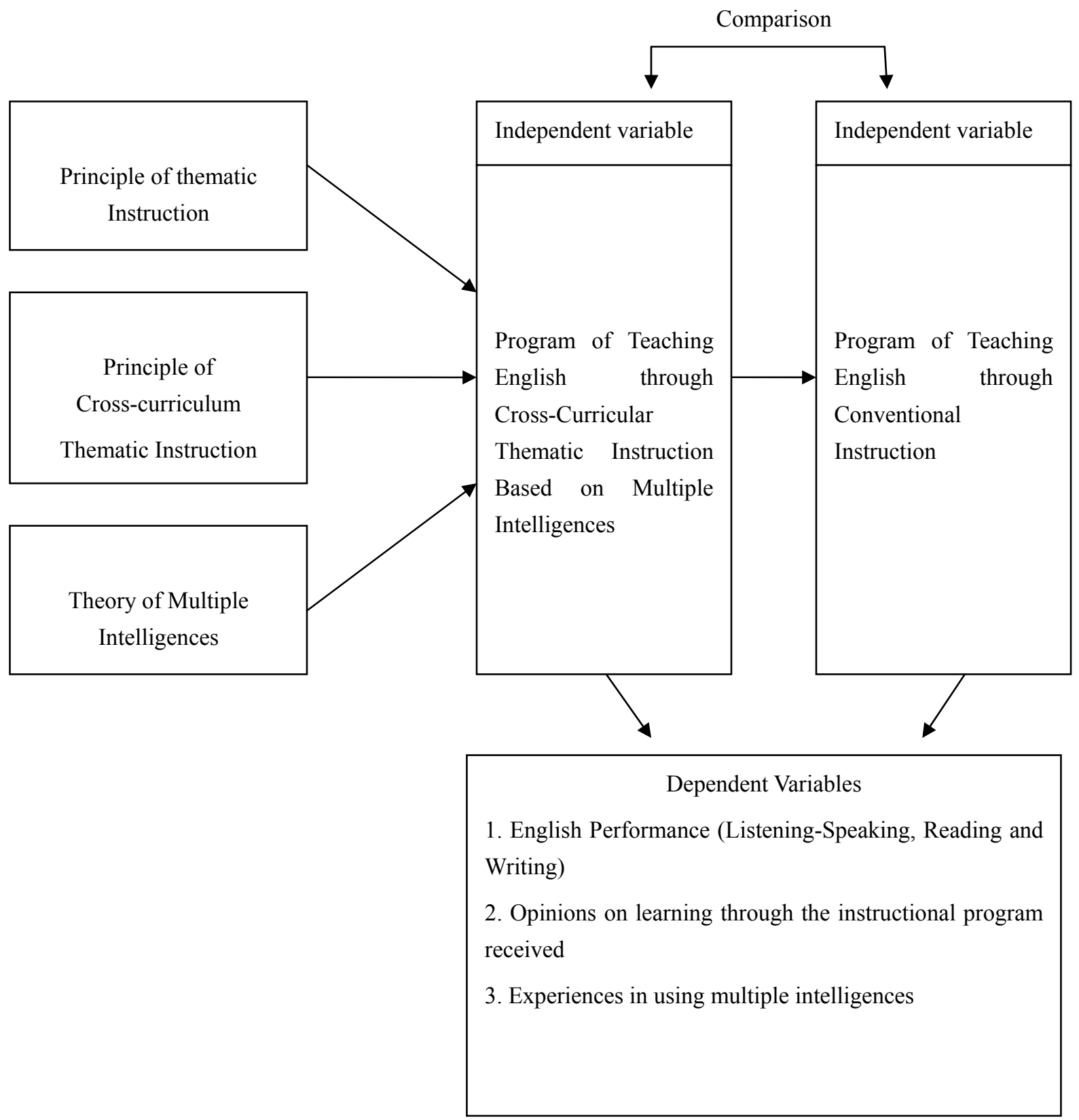

\subsection{Hypotheses of the Study}

Based on the research objectives and literature review, the following hypotheses were formulated for this study:

Hypothesis 1. Development of English performance (listening-speaking, reading and writing) of teacher-students taught through the program of cross-curricular thematic instruction based on multiple intelligence theory is higher than that taught through conventional instruction after the experiment.

Hypothesis 2. Teacher-students have higher positive opinion for the program of cross-curricular thematic instruction based on multiple intelligence theory than that for the learning program through conventional instruction.

Hypothesis 3. The teacher-students, taught through the program of cross-curricular thematic instruction based on 
multiple intelligence theory, find their experience of using multiple intelligences in each and all the eight aspects better than do the teacher-students taught through the conventional instruction after experiment.

\subsection{Research Questions}

According to the hypothesis, the questions of this research are stated as follows:

Question 1. Is there a significant difference in language performance (listening-speaking, reading and writing) between the development of experimental groups (B02 \& B04) and that of the control groups (B01 \& B04), and what is the percentage of the language performance of each group after development through the treatment given?

Question 2. Are the experimental groups' opinions on instructional learning program significantly more positive than those of the control groups?

Question 3. Do the experimental group teacher-students really identify their experiences in using multiple -intelligences more than the control groups do after treatment?

\section{Methodology}

\subsection{Research Design}

A Randomized True Control Group-Pretest-Posttest Time Series design was used in the study.

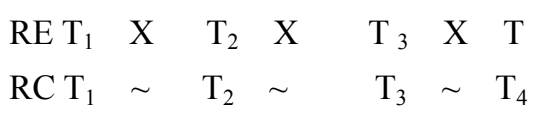

$[\mathrm{RE}=$ Randomized Experimental group $\quad \mathrm{RC}=$ Randomized Control group

$\mathrm{X}=$ Experimental group treatment $\sim=$ Control group treatment

$\mathrm{T}_{1}=$ pretest $\quad \mathrm{T}_{2}=$ posttest $1 \quad \mathrm{~T}_{3}=$ posttest $2 \quad \mathrm{~T}_{4}=$ posttest 3$]$

In 12 weeks with 36 teaching hours (excluding pretest and posttest sessions), the experimental groups were taught through the program of cross-curriculum thematic instruction based on multiple intelligence theory, and the control groups through conventional instruction. Both experimental and control groups were administered the pretest, followed by the posttest after every 2 weeks of treatment or one completed learning unit. The experimental and control groups were simultaneously administered the same three posttests after treatment in each unit.

\subsection{Sample of the Study}

The study sample comprised four groups of Srinakharinwirot University undergraduate teacher-students in Education, enrolled for the 2010 second semester (November 2010-March 2011) course of English for Learning Development (ED 352). They were assigned, through simple random sampling technique, to two experimental groups (B02 and B03) and two control groups (B01 and B04), each consisting of 20 students.

\subsection{Research Instruments}

The research instruments employed for data collection included three multiple-choice and cloze test-type reading equivalency tests (with a reliability of $0.85,0.93$, and 0.81 respectively, calculated by Pearson's Correlation Coefficient), one listening-speaking interview test (with a reliability of 0.89 , calculated by Cronbach Alpha Coefficient), one essay writing test (with a reliability of 0.81 , calculated by Cronbach Alpha Coefficient), five-choice Likert scale questionnaires on opinions about learning through the instructional programs (with a reliability of 0.95 , calculated by Cronbach Alpha Coefficient) and self-evaluation questionnaires on using 8 multiple intelligence activities (with a validity value between .67-1.00, calculated by Rovinelli \& Hambleton's Index of Item-Objective Congruence). The activities concerned mainly linguistic intelligence, logical and mathematical intelligence, visual/spatial intelligence, bodily kinesthetic intelligence, musical intelligence, interpersonal intelligence, intrapersonal intelligence, and naturalist intelligence.

\subsection{Treatment of the Study}

In 12 weeks, with 36 teaching hours (excluding pretest and posttest sessions), the experimental groups were taught through the program of cross-curriculum thematic instruction based on multiple intelligence theory, and the control groups through conventional instruction. The program of instruction to both groups was planned as 6 learning units for 36 teaching hours, 3 hours/week. The steps of the lesson for each program were planned as follows:

Experimental groups (B02 \& B03): 
Step 1. Let students listen to or read the thematic text and summarize the text orally or in writing.

Step 2. In small groups, let students work on different activities mainly in listening-speaking, reading and writing from related topics in different content areas across the curriculum by emphasizing each activity and covering each aspect of eight multiple intelligences (For example, listening to the news/reading a short new text/ article related to the topic in step 1(linguistic); discussing concepts/reasoning about the issues, using computer to search for answers (logical/mathematical); drawing pictures about the text, using map and diagram/charts for learning ( visual spatial); role playing /acting mini drama, using gestures to express bodily information /feeling (body kinesthetic); listening to/singing the songs related to the learning issue, imitating voices or sounds (musical); brainstorming/discussing in group activities, group working with friends (interpersonal); self-testing, answering questionnaires or self-attitudes evaluation after learning ,expressing personal feelings to others (intrapersonal); searching natural issues about nature on humans, animals, and environments, observing natural phenomenon in actual/simulation situations (naturalist), etc.)

Step 3. In small groups or as individuals, let students independently seek further studies on any topic concerning the previous lesson, according to their interest, and write the report for presentation in class.

Step 4. Let students take turns in presenting their group work or individual work in class while other students ask questions and comment on the presentation, discuss and correct the language use appropriately under teacher's supervision and recommendation. Allow students to organize their display boards for presentation or other activity programs such as mini drama, debate, project planning, etc

(As students are nonnative English language users, so the teacher allows the students to first speak in Thai whenever they feel difficulty in speaking/reading and writing in English and scaffold or assist them to translate into English afterward. The teacher also organizes the recognition program for students after students' presentation by using simple but impressive techniques such as listing the names of all the students, who achieved, on the board of fame in class or outside the class, organizing certificate of recognition ceremony in class, giving awards, etc)

Control groups (B01 \& B04):

Step 1. Let students listen to or read the text (the same one used by the experimental groups).

Step 2. Let students, in small groups, summarize the text they listened to.

Step 3. Let each group of students present their writing and keep it open for discussion and correction of language use under teacher's supervision.

Step 4. Let each group of students independently write a new text and discuss its language for correction.

Step 5. The teacher reviews all the mistakes of the students and explains how to correct them.

\subsection{Data Analysis}

Each hypothesis was tested by using SPSS computer program as follows:

Hypothesis 1. Compared the scores of the three tests of language performance (listening-speaking, reading, and writing) of the two experimental and the two control groups' pretest and other three posttests, using MANOVA with repeated measures for within and between groups analysis through the processes of univariate test, multivariate test, posthoc test, simple effects analysis, and analysis of effect size results of the treatment in each group (partial $\eta^{2}$ ). For independent samples, $t$-test was used to compare the significant differences in the overall development of each language performance (listening-speaking, reading, and writing skills) between the experimental and control groups. Finally, line figures were used for a summary of the results of data analyses.

Hypothesis 2. The data of the experimental and control groups were analyzed using basic statistics ( $\overline{\mathrm{X}}$ and SD) and the opinion results finalized by using the rating criteria (least, little, moderate, much and most) to compare aspect-wise and overall results between the experimental and control groups.

For independent samples, $t$-test was used to compare the significance of differences for each aspect between the experimental and control groups.

Hypothesis 3. Compared the scores tallied from self-evaluation forms of multiple intelligence activities used in classes of both experimental and control groups and analyzed the scores in each item of the two experimental and the two control groups through basic statistical analysis ( $\bar{X}$ and S.D.). Summarized and compared aspect-wise and overall results of multiple intelligence categories between the experimental and control groups using the rating criteria (least, little, moderate, much and most).Finally, line figures showing the results of overall differences in Multiple Intelligences between the experimental and control groups were also plotted. 


\section{Results of the Study}

Research question 1: Is there a significant difference in language development between the experimental and control groups and what is the percentage of each group's language performance after treatment?

The data presented in Table 1 and Figure 1 show that both the experimental groups registered significantly higher development in English language performance (reading, listening-speaking, and writing) than did the control groups at .01 level.

Table 1. Test of significant differences of the development in reading, writing, and listening-speaking performances between the experimental and control groups using $t$-test for independent samples

\begin{tabular}{|c|c|c|c|c|c|c|}
\hline \multirow[t]{2}{*}{ Language Skills } & \multirow[t]{2}{*}{ Groups } & \multirow[t]{2}{*}{$\mathrm{n}$} & \multicolumn{2}{|c|}{$\begin{array}{c}\text { Scores of } \\
\text { Performance }\end{array}$} & \multirow[t]{2}{*}{$\mathrm{t}$} & \multirow[t]{2}{*}{$\mathrm{p}$-Value } \\
\hline & & & $\overline{\mathrm{X}}$ & $\mathrm{SD}$ & & \\
\hline \multirow[t]{2}{*}{ Reading } & Experimental & 40 & 13.50 & 0.82 & \multirow{2}{*}{9.327} & \multirow{2}{*}{.000} \\
\hline & Control & 40 & 10.33 & 1.99 & & \\
\hline \multirow[t]{2}{*}{ Writing } & Experimental & 40 & 13.35 & 0.86 & \multirow{2}{*}{10.316} & \multirow{2}{*}{.000} \\
\hline & Control & 40 & 11.08 & 1.10 & & \\
\hline \multirow[t]{2}{*}{ Listening-Speaking } & Experimental & 40 & 13.40 & 0.74 & \multirow{2}{*}{10.798} & \multirow{2}{*}{.000} \\
\hline & Control & 40 & 11.48 & 0.85 & & \\
\hline
\end{tabular}

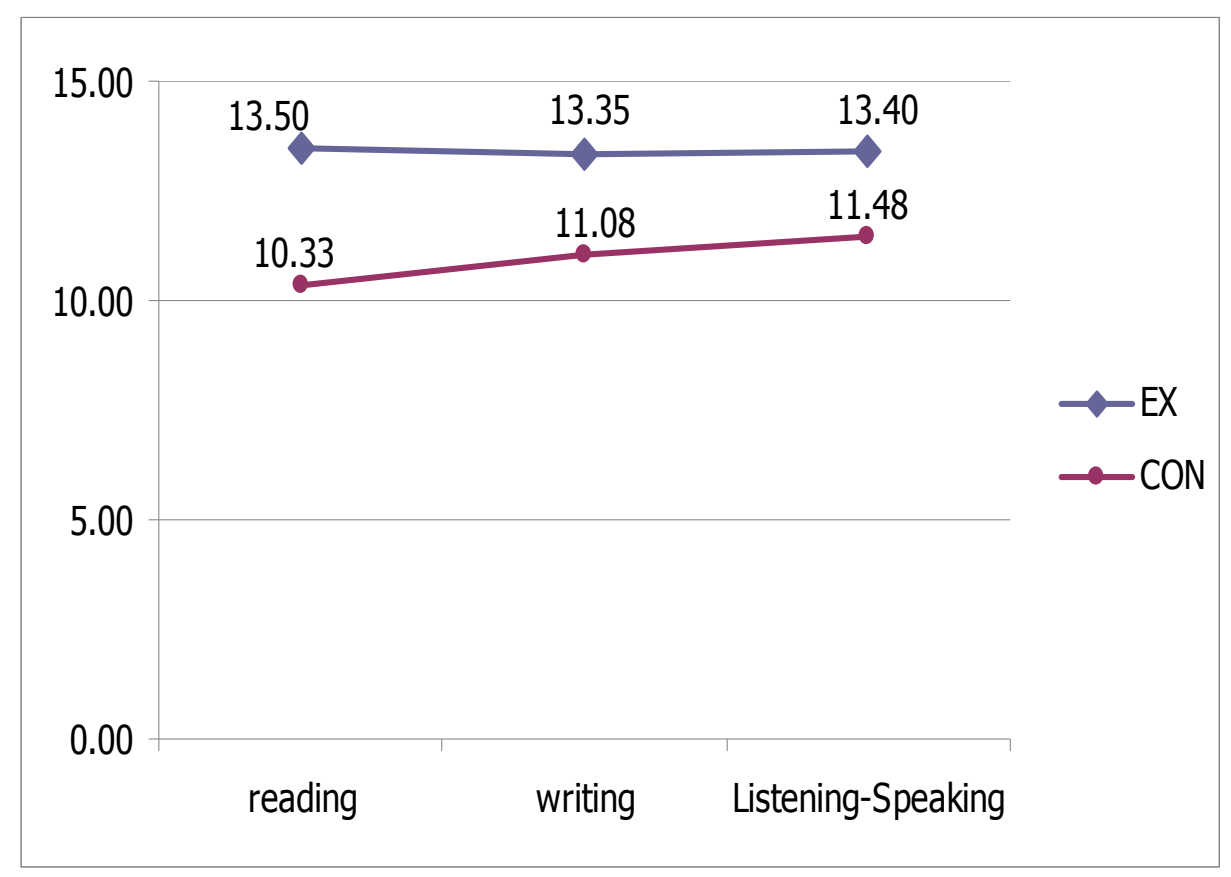

Figure 1. Comparison of the development in reading, writing, and listening-speaking performances between the experimental and control groups after the experiment

Data presented in Tables 2, 3, and 4, and in Figure 2, show that after the experiment, the experimental groups improved their reading performance by $91 \%$ (B02) and 92\% (B03), listening-speaking performance by $85 \%$ (B02) and 90\% (B03), and writing performance by $91 \%$ (B02) and 95\% (B03). The control groups improved their reading performance by $5 \%(\mathrm{~B} 01)$ and $50 \%$ (B04), listening-speaking performance by $12 \%(\mathrm{~B} 01)$ and $55 \%$ (B04), and writing performance by $72 \%$ (B01) and 91\% (B04). 
Table 2. Comparison of the development in listening-speaking performance of the experimental and control groups through the analysis of MANOVA of repeated measures

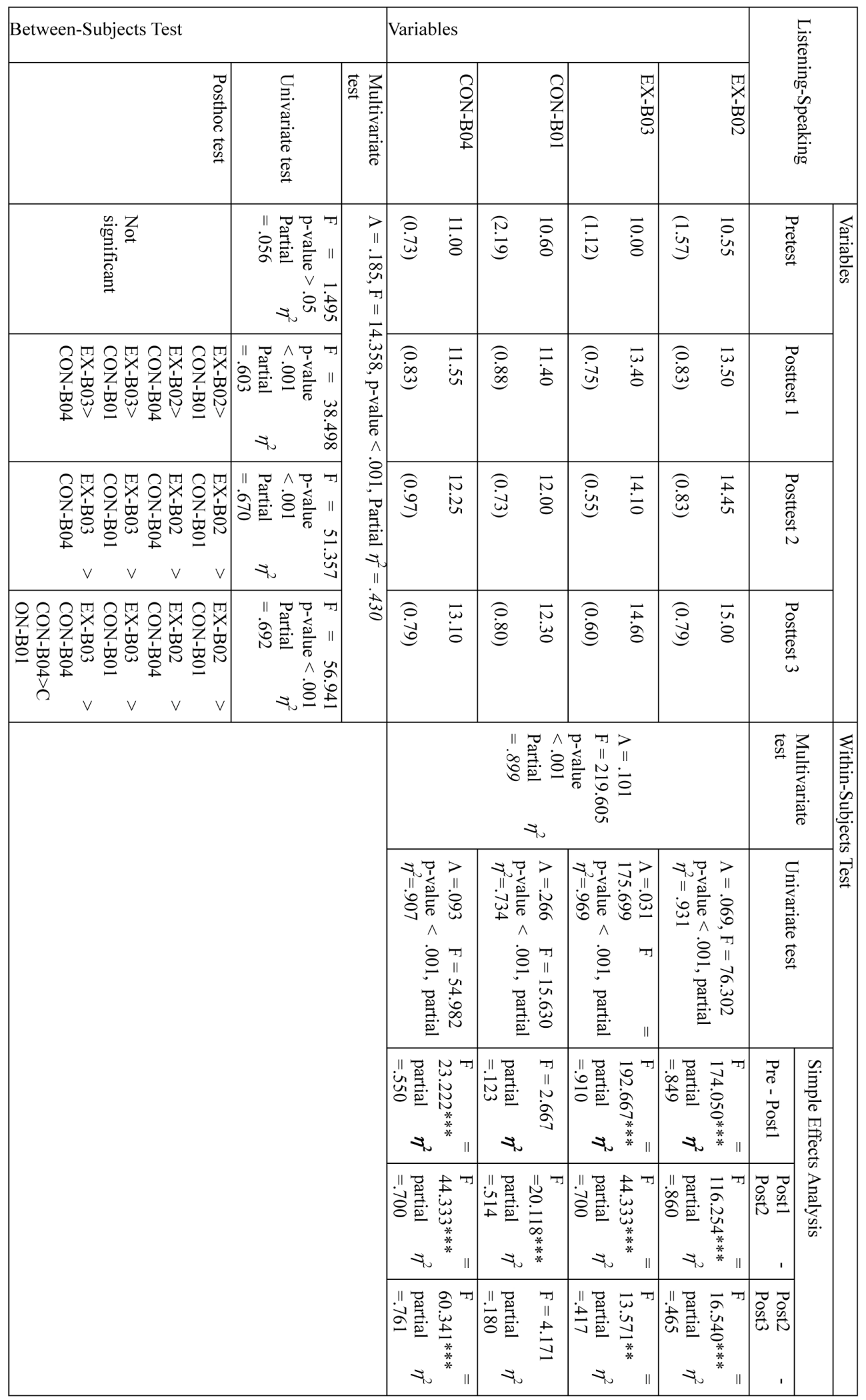

Note: The number in $(\ldots$.$) is \mathrm{SD} * * *=\mathrm{p}$-value $<.001, * *=\mathrm{p}$-value $<.01, *=\mathrm{p}$-value $<.05$. 
Table 3. Comparison of the development in reading performance between the experimental and control groups through the analysis of MANOVA with repeated measures

\begin{tabular}{|c|c|c|c|c|c|c|c|c|c|}
\hline \multicolumn{3}{|l|}{ Between-Subjects Test } & \multicolumn{4}{|l|}{ Variables } & \multirow{2}{*}{\multicolumn{3}{|c|}{ 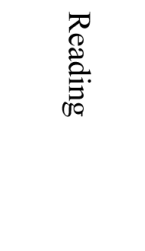 }} \\
\hline 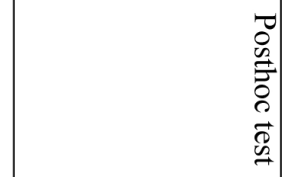 & 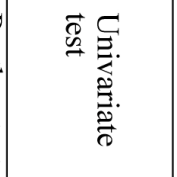 & 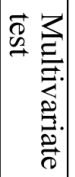 & 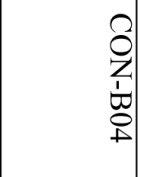 & 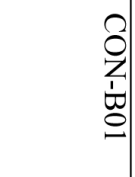 & 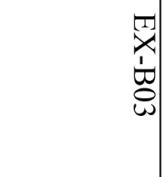 & 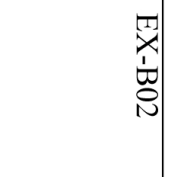 & & & \\
\hline 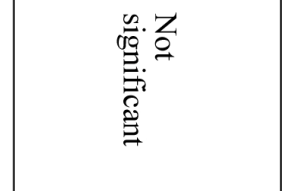 & 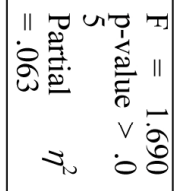 & \multirow{4}{*}{ 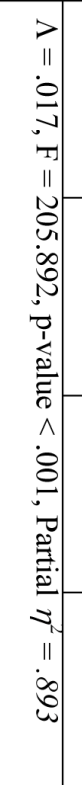 } & 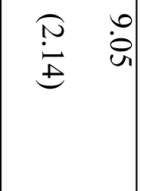 & 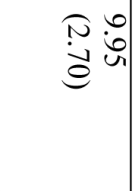 & 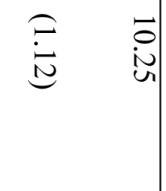 & $\widehat{\vec{\sigma}}$ & & & 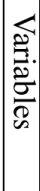 \\
\hline 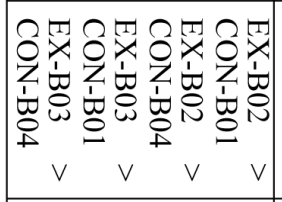 & 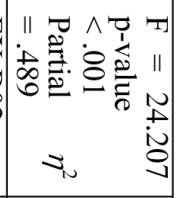 & & 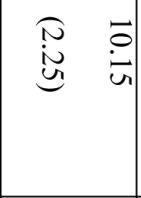 & 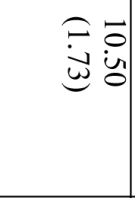 & $\begin{array}{ll}\hat{0} & \vec{\omega} \\
\dot{\infty} & \ddot{0}\end{array}$ & 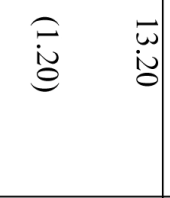 & \multicolumn{2}{|c|}{ 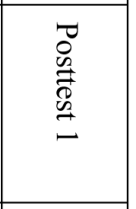 } & \\
\hline 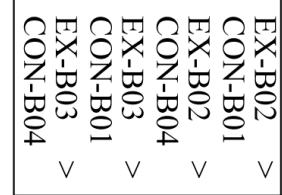 & 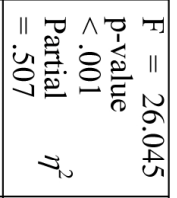 & & $\begin{array}{|ll|}\overrightarrow{6} & \overline{0} \\
\hat{\theta} & \dot{8} \\
\end{array}$ & 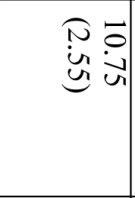 & $\begin{array}{ll}\stackrel{\vec{j}}{\tilde{U}} & \overrightarrow{\dot{\theta}}\end{array}$ & $\begin{array}{ll}\stackrel{F}{\oplus} & \square \\
\dot{8} & \end{array}$ & \multicolumn{2}{|c|}{ 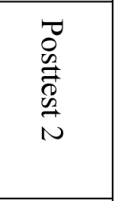 } & \\
\hline 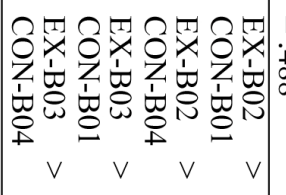 & 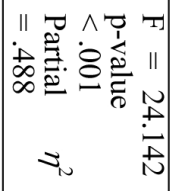 & & 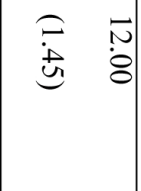 & 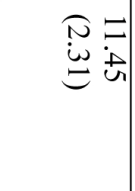 & $\begin{array}{cc}\overline{\dot{\omega}} & \bar{u} \\
\stackrel{0}{\infty} & \dot{0}\end{array}$ & $\begin{array}{ll}\stackrel{ \pm}{ \pm} & \stackrel{ \pm}{ \pm}\end{array}$ & \multicolumn{2}{|c|}{$\begin{array}{l}\overrightarrow{0} \\
0 \\
0 \\
00 \\
0 \\
0 \\
\omega \\
\end{array}$} & \\
\hline & & & \multicolumn{4}{|c|}{ 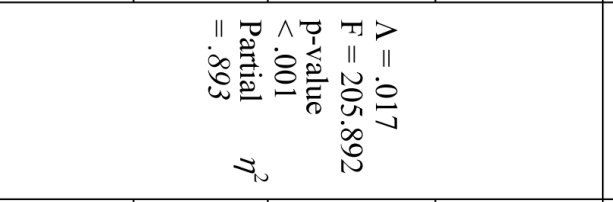 } & \multicolumn{2}{|c|}{. } & 离. \\
\hline & & & 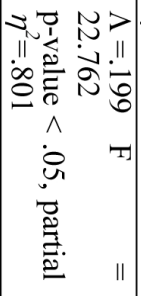 & 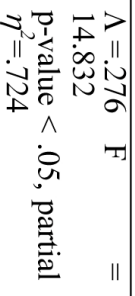 & 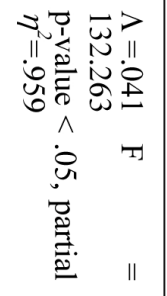 & 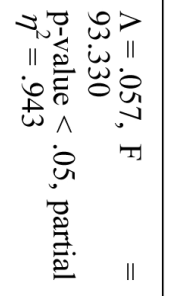 & 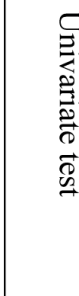 & & 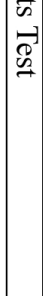 \\
\hline & & & 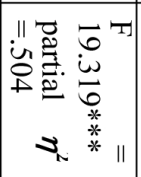 & 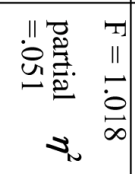 & 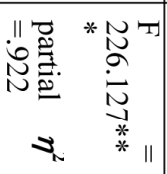 & 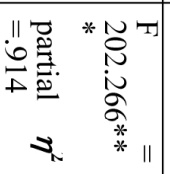 & \begin{tabular}{l|}
$\overrightarrow{0}$ \\
$\overrightarrow{0}$ \\
1 \\
$\overrightarrow{0}$ \\
$\stackrel{0}{=}$
\end{tabular} & 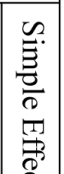 & \\
\hline & & & 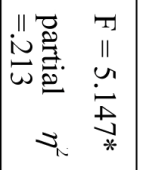 & 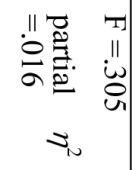 & 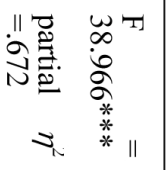 & 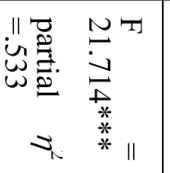 & 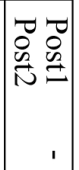 & 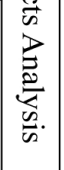 & \\
\hline & & & 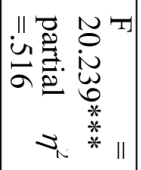 & 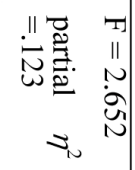 & 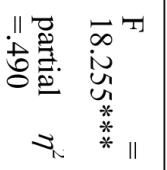 & 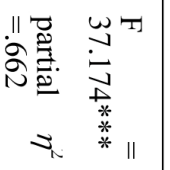 & 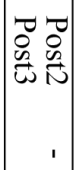 & & \\
\hline
\end{tabular}

Note: The number in the $(\ldots)$ is $\mathrm{SD} * * *=\mathrm{p}$-value $<.001, * *=$ p-value $<.01, *=\mathrm{p}$-value $<.05$. 
Table 4. Comparison of the development in writing performance between the experimental and control groups through the analysis of MANOVA with repeated measures

\begin{tabular}{|c|c|c|c|c|c|c|c|c|c|}
\hline \multicolumn{3}{|l|}{ Between-Subjects Test } & \multicolumn{4}{|l|}{ Variables } & \multirow{2}{*}{\multicolumn{3}{|c|}{ 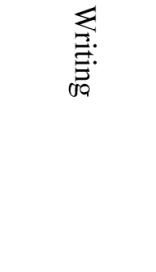 }} \\
\hline 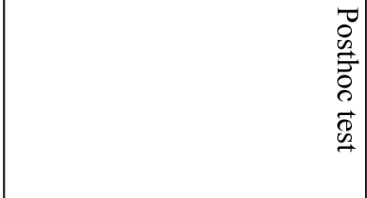 & 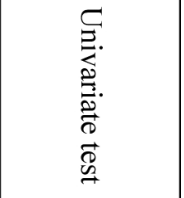 & 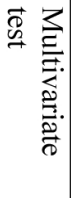 & 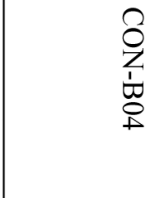 & $\begin{array}{l}\hat{\sigma} \\
z \\
1 \\
0 \\
0\end{array}$ & 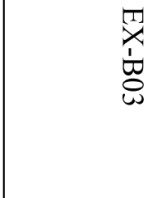 & 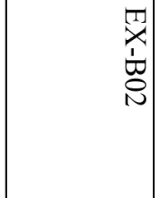 & & & \\
\hline 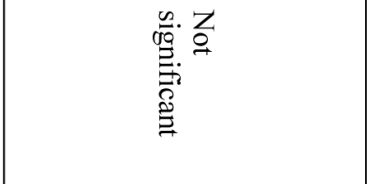 & 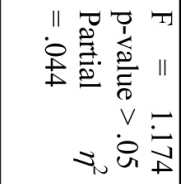 & $\begin{array}{l}> \\
11 \\
: \\
0 \\
0 \\
11 \\
11\end{array}$ & $\begin{array}{ll}\text { Oे } & \text { o } \\
\text { i } & \text { i }\end{array}$ & 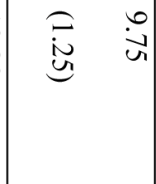 & 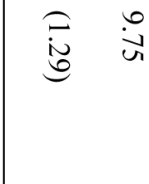 & 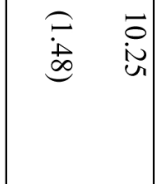 & 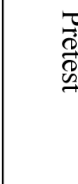 & & \\
\hline 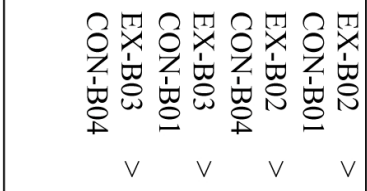 & 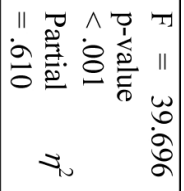 & 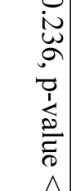 & 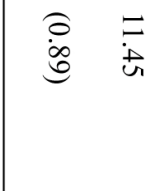 & $\begin{array}{ll}\stackrel{\vec{\Xi}}{\vec{y}} & \overrightarrow{0} \\
\dot{0}\end{array}$ & 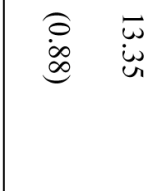 & $\begin{array}{ll}0 & \omega \\
\dot{0} & 0 \\
\pm & \dot{t}\end{array}$ & 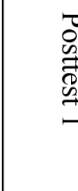 & & \\
\hline 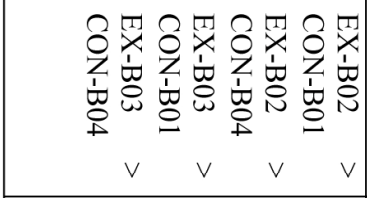 & 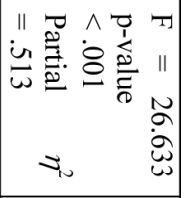 & 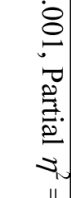 & 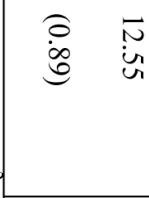 & 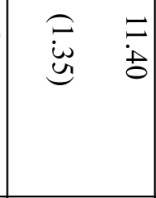 & $\begin{array}{ll}\hat{0} & \stackrel{1}{0} \\
\dot{0} & 8\end{array}$ & $\begin{array}{cc}\overrightarrow{:} & \vec{\omega} \\
\overrightarrow{0} & \dot{0}\end{array}$ & 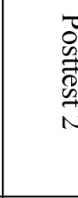 & & \\
\hline 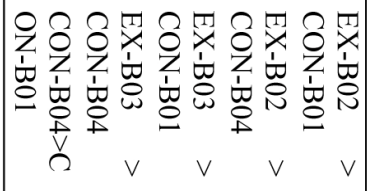 & 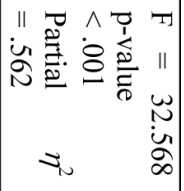 & $\stackrel{i}{i}$ & $\begin{array}{ll}\overrightarrow{\dot{\theta}} & \vec{c} \\
\dot{0}\end{array}$ & 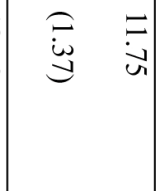 & $\stackrel{\overrightarrow{0}}{\stackrel{P}{\theta}}$ & 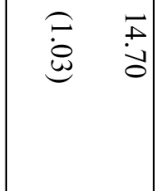 & $\begin{array}{l}\text { To } \\
0 \\
\overline{0} \\
\text { th }\end{array}$ & & \\
\hline & & & & 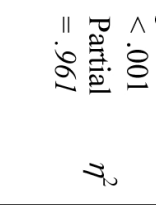 & 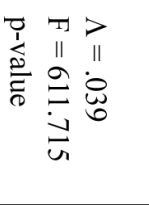 & & & 这. & \\
\hline & & & 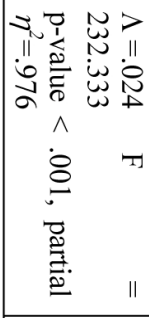 & 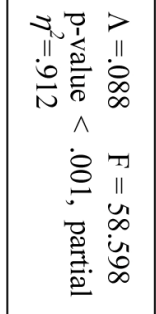 & 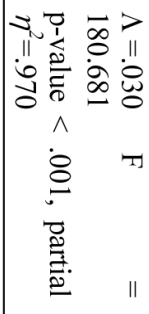 & 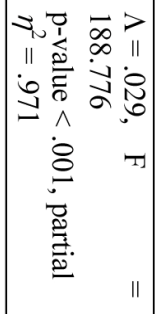 & 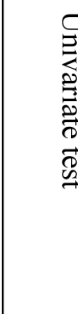 & & 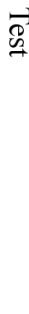 \\
\hline & & & 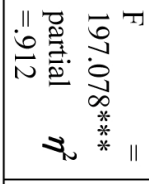 & 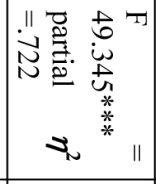 & 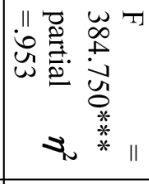 & 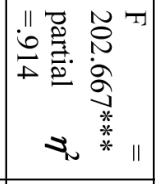 & $\begin{array}{l}0 \\
0 \\
1 \\
0 \\
0 \\
0\end{array}$ & 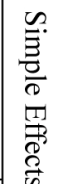 & \\
\hline & & & 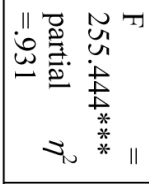 & 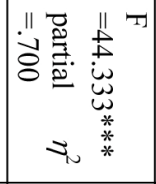 & 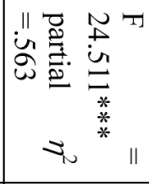 & 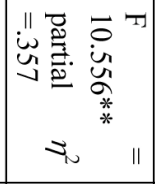 & $\mid \begin{array}{ll}0 & 0 \\
0 & 0 \\
0 & 0 \\
& 0 \\
\end{array}$ & 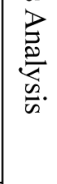 & \\
\hline & & & 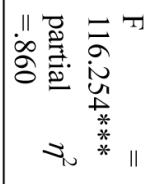 & 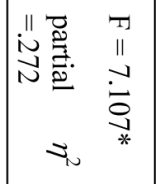 & 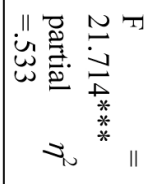 & 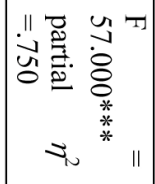 & 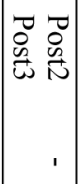 & & \\
\hline
\end{tabular}



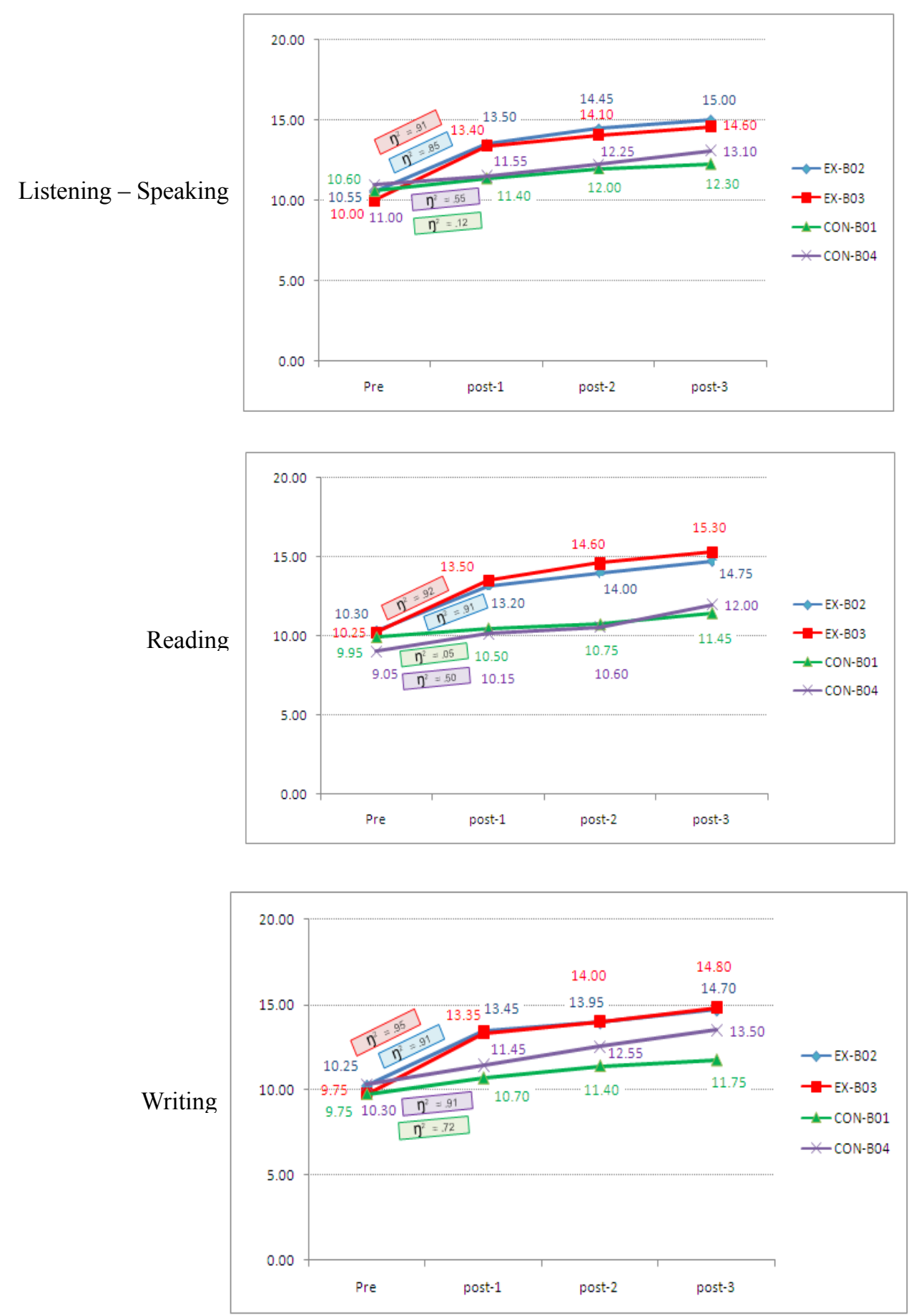

Figure 2. Comparison of the development in listening-speaking, reading, and writing performances between the experimental ( B02 \& B03) and control groups (B01 \& B04) shown by line figures

Research question 2. Are the experimental groups' opinions on instructional learning program significantly more positive than those of the control groups?

Data presented in Tables 5 and 6 show that both the experimental groups registered significantly higher positive opinions at .01 level on the instruction used than did the control groups on the conventional instruction. 
Table 5. Test of significant difference in the overall opinion about learning program used in English for learning development course between the experimental (B02 \& B03) and control groups (B01 \& B04), using $t$-test for independent samples

\begin{tabular}{|c|c|c|c|c|c|}
\hline \multirow{2}{*}{ Groups } & \multirow{2}{*}{$\mathrm{n}$} & \multicolumn{2}{|c|}{ Opinions } & \multirow{2}{*}{$\mathrm{t}$} & \multirow{2}{*}{ p-Value } \\
\hline & & $\overline{\mathrm{X}}$ & SD & & \\
\hline Experimental & 40 & 4.00 & 0.38 & \multirow{2}{*}{16.262} & \multirow{2}{*}{.000} \\
\hline Control & 40 & 2.96 & 0.14 & & \\
\hline
\end{tabular}

Table 6. Analysis of basic statistical data between the experimental and control groups'opinions on learning program used in English for learning course

\begin{tabular}{|c|c|c|c|c|}
\hline \multirow{2}{*}{ Opinions } & \multicolumn{2}{|c|}{$\begin{array}{l}\text { Experimental } \\
\text { Group }\end{array}$} & \multicolumn{2}{|c|}{ Control Group } \\
\hline & $\overline{\mathrm{X}}$ & SD & $\overline{\mathrm{X}}$ & SD \\
\hline $\begin{array}{l}\text { 1. The learning program in this course is very useful to develop } \\
\text { my English for interpretation/communication. }\end{array}$ & 4.25 & 0.44 & 3.70 & 0.46 \\
\hline $\begin{array}{l}\text { 2. The learning program in this course enables me to have } \\
\text { broader opportunities in learning more variety of issues or } \\
\text { content areas. }\end{array}$ & 4.55 & 0.50 & 2.98 & 0.53 \\
\hline $\begin{array}{l}\text { 3. The learning program in this course enables me to develop } \\
\text { broader learning in vocabularies/idioms. }\end{array}$ & 3.90 & 0.63 & 3.33 & 0.47 \\
\hline $\begin{array}{l}\text { 4. The learning program in this course attracts me to participate } \\
\text { in various activities relevant to my interest and aptitudes. }\end{array}$ & 4.13 & 0.65 & 2.85 & 0.66 \\
\hline $\begin{array}{l}\text { 5. The learning program in this course is very interesting and } \\
\text { attractive for an ongoing learning. }\end{array}$ & 3.90 & 0.59 & 3.35 & 0.66 \\
\hline $\begin{array}{l}\text { 6. I have lots of opportunities in listening-speaking and } \\
\text { expressing my opinions. }\end{array}$ & 3.88 & 0.61 & 2.85 & 0.58 \\
\hline $\begin{array}{l}\text { 7. I always have opportunities in group working activities with } \\
\text { other students. }\end{array}$ & 4.35 & 0.77 & 3.58 & 0.50 \\
\hline $\begin{array}{l}\text { 8. I have opportunities in independently searching and studying } \\
\text { more knowledge according to my interest and aptitude. }\end{array}$ & 3.98 & 0.80 & 2.98 & 0.58 \\
\hline $\begin{array}{l}\text { 9. I feel that I can show improvement in listening to and } \\
\text { speaking in English. }\end{array}$ & 3.88 & 0.76 & 2.68 & 0.57 \\
\hline $\begin{array}{l}\text { 10. I feel that I can better grasp the main ideas in reading/getting } \\
\text { better details of reading. }\end{array}$ & 3.88 & 0.72 & 2.65 & 0.58 \\
\hline 11. I feel that I can write better in English on various topics. & 3.90 & 0.78 & 2.38 & 0.49 \\
\hline $\begin{array}{l}\text { 12. In this course, there was a well-prepared program of learning } \\
\text { materials, audio-visual aids, and equipments to assist students in } \\
\text { better learning for understanding and feasibly practicing } \\
\text { activities. }\end{array}$ & 4.03 & 0.70 & 3.40 & 0.50 \\
\hline $\begin{array}{l}\text { 13. In this learning program, the teacher always integrates some } \\
\text { moral and ethical issues for students. }\end{array}$ & 4.30 & 0.46 & 2.85 & 0.53 \\
\hline 14. I can always evaluate and assess my learning in this course. & 4.30 & 0.46 & 3.03 & 0.62 \\
\hline $\begin{array}{l}\text { 15. There are various ways of consistent measurement and } \\
\text { evaluation in the learning program that makes me vibrant. }\end{array}$ & 4.35 & 0.58 & 2.90 & 0.30 \\
\hline $\begin{array}{l}\text { 16. I can apply information/knowledge from this course to other } \\
\text { subject areas in my learning curriculum. }\end{array}$ & 3.70 & 0.69 & 2.60 & 0.59 \\
\hline 17. I have learned more by working with others after completing & 3.75 & 0.63 & 2.98 & 0.36 \\
\hline
\end{tabular}




\section{this course.}

18. I always have opportunities of discussing and consulting with the teacher and other classmates.

$\begin{array}{llll}3.75 & 0.63 & 2.55 & 0.50\end{array}$

19. I have more opportunities of learning and exchanging information with classmates and others.

$\begin{array}{llll}3.90 & 0.63 & 2.40 & 0.50\end{array}$

20. I actualize that learning English should relate to other rounded information for interpreting and communicating our own ideas with others.

21. I feel I have a better relationship with friends and others.

22. I feel more self-confident in communication/interpretation in English with others.

$\begin{array}{llll}3.50 & 0.68 & 2.58 & 0.50\end{array}$

23. I enjoy learning with friends and the teacher in this course.

4.15

0.48

3.50

0.51

Total

4.00

0.38

2.96

0.14

Table 7. Criteria for data interpretation

\begin{tabular}{ll}
\hline Criteria & Level of Opinions \\
\hline $4.50-5.00$ & Most \\
$3.50-4.49$ & Much \\
$2.50-3.49$ & Moderate \\
$1.50-2.49$ & Little \\
$0.00-1.49$ & Least \\
\hline
\end{tabular}

Research question 3. Do the experimental group teacher-students really identify their experiences in using multiple -intelligences more than what the control groups do after the experiment?

Data presented in Tables 7 and 8 and Figure 3 show that, after the experiment, both experimental groups

Identified greater percentage of experience in using each and all the aspects of multiple intelligences than did the control groups.

Table 8. Analysis of differences in self-evaluation on experiences in using multiple intelligences between the experimental and control groups

\begin{tabular}{lccc}
\hline & \multicolumn{2}{c}{$\begin{array}{c}\text { Percentage of Multiple } \\
\text { Intelligence Use }\end{array}$} \\
\cline { 2 - 3 } Aspect of Multiple Intelligence & $\begin{array}{c}\text { Experimental } \\
\text { Groups }\end{array}$ & $\begin{array}{c}\text { Control } \\
\text { Groups }\end{array}$ \\
\cline { 2 - 3 } 1. Linguistic Intelligence & 100 & 79 & 21 \\
2. Logical-Mathematical Intelligence & 91 & 25 & 66 \\
3. Visual-Spatial Intelligence & 84 & 95 \\
4. Bodily Kinesthetic Intelligence & 94 & 25 & 69 \\
5. Musical Intelligence & 65 & 30 & 35 \\
6. Interpersonal Intelligence & 87 & 60 & 27 \\
7. Intrapersonal Intelligence & 93 & 48 & 45 \\
8. Naturalist Intelligence & 70 & 0 & 70 \\
\hline
\end{tabular}


Table 9. Analysis of basic statistical data of the experimental and control groups' experiences in using multiple intelligences in English for learning development course

Evaluation of Multiple Intelligence Use

\begin{tabular}{cccccc}
\multicolumn{3}{c}{ Experimental Group } & \multicolumn{3}{c}{ Control Group } \\
\hline$\%$ & $\overline{\mathrm{X}}$ & SD & $\%$ & $\overline{\mathrm{X}}$ & $\mathrm{SD}$
\end{tabular}

\section{Linguistic Intelligence}

1. Speaking/conversing in English in various activity contexts.

2. Listening to different topics/issues in English.

$\begin{array}{llllll}100 & 1.00 & 0.00 & 100 & 1.00 & 0.00 \\ 100 & 1.00 & 0.00 & 100 & 1.00 & 0.00 \\ 100 & 1.00 & 0.00 & 100 & 1.00 & 0.00 \\ 100 & 1.00 & 0.00 & 100 & 1.00 & 0.00 \\ 100 & 1.00 & 0.00 & 100 & 1.00 & 0.00 \\ 100 & 1.00 & 0.00 & 100 & 1.00 & 0.00 \\ 100 & 1.00 & 0.00 & 53 & 0.53 & 0.51 \\ 100 & 1.00 & 0.00 & 79 & 0.79 & 0.07\end{array}$

3. Reading various issues/literary works/articles in English. 100

4. Playing games for skill practice in English in different contexts.

5. Writing vocabulary items/sentences in English in different occasions and contexts.

6. Writing essays/summary of texts in English.

7. Spelling English vocabularies in different activities.

Overall Aspect of Linguistic Intelligence

Logical and Mathematical Intelligence

8. Practicing activities about numbers/calculating/counting/statistical analyzing.

9. Playing critical thinking games.

10. Discussing concepts/reasoning about different issues.

11. Using computer to search for answers/responses.

Overall Aspects of Logical/Mathematical Intelligence

Visual-Spatial Intelligence

12. Drawing pictures/doing activities.

13. Watching movies/slides/DVD/PowerPoints/looking at pictures.

14. Using the map/diagrams/charts for learning.

100

$\begin{array}{lllll}1.00 & 0.00 & 0 & 0.00 & 0.00\end{array}$

100

1.00

$0.00 \quad 0$

0.00

0.00

100

1.00

0.00

100

1.00

0.00

63

0.63

$0.49 \quad 0$

0.00

0.00

91

0.91

$0.12 \quad 25$

0.25

0.00

100

1.00

0.00

1.00

1.00

0.00

100

1.00

0.00

1.00

1.00

0.00

73

0.73

0.45

0

0.00

0.00

63

0.63

$0.49 \quad 1.00$

1.00

0.00

84

0.84

0.1

0.75

0.00

Bodily Kinesthetic Intelligence

16. Doing activities using bodily movement in different ways, such as walking, running, dancing, turning around, etc.

0.00

0.00

0.00

17. Using gestures to express bodily information/feeling in different activities, such as raising hands, nodding head, etc.

18. Role playing/acting mini drama, etc.

$\begin{array}{llllll}100 & 1.00 & 0.00 & 100 & 1.00 & 0.00\end{array}$

19. Doing handicraft activities/carpentry, etc.

100

$\begin{array}{lllll}1.00 & 0.00 & 0 & 0.00 & 0.00\end{array}$

Overall Aspect of Bodily Kinesthetic Intelligence

$0.44 \quad 0$

$0.00 \quad 0.00$ 
20. Listening to music/other sounds, etc.

21. Singing (individually/in chorus).

22. Playing musical instrument.

23. Doing activities with rhythmic background.

24. Imitating voices/sounds.

Overall Aspect of Musical Intelligence

Interpersonal Intelligence

25. Group working with friends/others.

26. Fellowship/friendship activities/social activities for learning, such as participating in social activities with friends or meeting others for learning activities.

27. Participating in groups for exchanging idea activities/brainstorming/discussing.

28. Participating in community activities.

29. Being assistant/facilitator/moderator in group activities.

Overall Aspect of Interpersonal Intelligence

Intrapersonal Intelligence

30. Independently studying for other knowledge /information/self-studying in different ways

31. Self-studying through self-study learning program/module.

32. Independently conducting projects or playing games.

33. Noting/making his/her diary.

34. Giving his/her information to others.

35. Analyzing his/her strengths and weaknesses.

36. Expressing personal feelings to others.

37. Formulating his or her goals in activities.

38. Self-evaluating, such as self-testing, answering questionnaires for self-attitude evaluation.

Overall Aspect of Intrapersonal Intelligence

Naturalist Intelligence

39. Field-trip studying in different places for learning.

40. Learning nature through pictures/videos/different media.

41. Learning nature by actual materials/situations.

42. Observing natural phenomenon in actual/simulation situations.

43. Field-trip studying outside class about nature.

44. Surveying activities/searching natural issues about nature (humans, animals, and environments).

Overall aspect of Naturalist Intelligence

$\begin{array}{llllll}100 & 1.00 & 0.00 & 1 & 1.00 & 0.00 \\ 100 & 1.00 & 0.00 & 50 & 0.50 & 0.51 \\ 0 & 0.00 & 0.00 & 0 & 0.00 & 0.00 \\ 25 & 0.25 & 0.44 & 0 & 0.00 & 0.00 \\ 100 & 1.00 & 0.00 & 0 & 0.00 & 0.00 \\ 65 & 0.65 & 0.09 & 30 & 0.30 & 0.10\end{array}$

$\begin{array}{llllll}100 & 1.00 & 0.00 & 100 & 1.00 & 0.00\end{array}$

$\begin{array}{llllll}100 & 1.00 & 0.00 & 0 & 0.00 & 0.00\end{array}$

$\begin{array}{llllll}100 & 1.00 & 0.00 & 100 & 1.00 & 0.00\end{array}$

$\begin{array}{llllll}35 & 0.35 & 0.48 & 0 & 0.00 & 0.00\end{array}$

$\begin{array}{llllll}100 & 1.00 & 0.00 & 100 & 1.00 & 0.00\end{array}$

$\begin{array}{llllll}87 & 0.87 & 0.10 & 60 & 0.60 & 0.00\end{array}$

$\begin{array}{llllll}100 & 1.00 & 0.00 & 100 & 1.00 & 0.00\end{array}$

$\begin{array}{llllll}100 & 1.00 & 0.00 & 100 & 1.00 & 0.00\end{array}$

$\begin{array}{llllll}100 & 1.00 & 0.00 & 0 & 0.00 & 0.00\end{array}$

$\begin{array}{llllll}100 & 1.00 & 0.00 & 100 & 1.00 & 0.00\end{array}$

$\begin{array}{llllll}100 & 1.00 & 0.00 & 35 & 0.35 & 0.48\end{array}$

$\begin{array}{llllll}80 & 0.80 & 0.41 & 0 & 0.00 & 0.00\end{array}$

$\begin{array}{llllll}70 & 0.70 & 0.46 & 0 & 0.00 & 0.00\end{array}$

$\begin{array}{llllll}88 & 0.88 & 0.33 & 50 & 0.00 & 0.51\end{array}$

$\begin{array}{llllll}100 & 1.00 & 0.00 & 50 & 0.00 & 0.51\end{array}$

$\begin{array}{llllll}93 & 0.93 & 0.09 & 48 & 0.48 & 0.05\end{array}$

$\begin{array}{llllll}55 & 0.55 & 0.50 & 0 & 0.00 & 0.00\end{array}$

$\begin{array}{llllll}100 & 1.00 & 0.00 & 0 & 0.00 & 0.00\end{array}$

$\begin{array}{llllll}63 & 0.63 & 0.49 & 0 & 0.00 & 0.00\end{array}$

$\begin{array}{llllll}60 & 0.60 & 0.50 & 0 & 0.00 & 0.00\end{array}$

$\begin{array}{llllll}45 & 0.45 & 0.50 & 0 & 0.00 & 0.00\end{array}$

$\begin{array}{llllll}100 & 1.00 & 0.00 & 0 & 0.00 & 0.00\end{array}$

$\begin{array}{llllll}70 & 0.70 & 0.18 & 0 & 0.00 & 0.00\end{array}$


Table 10. Criteria for Data Interpretation

\begin{tabular}{ll}
\hline Criteria & Level of Evaluation \\
\hline $0.88-1.00$ & Most \\
$0.66-0.87$ & Much \\
$0.44-0.65$ & Moderate \\
$0.22-0.43$ & Little \\
$0.00-0.21$ & Least \\
\hline
\end{tabular}

*Note: None of the teacher-students in the experimental and control groups added any other activity in the open-ended forms given for each aspect.

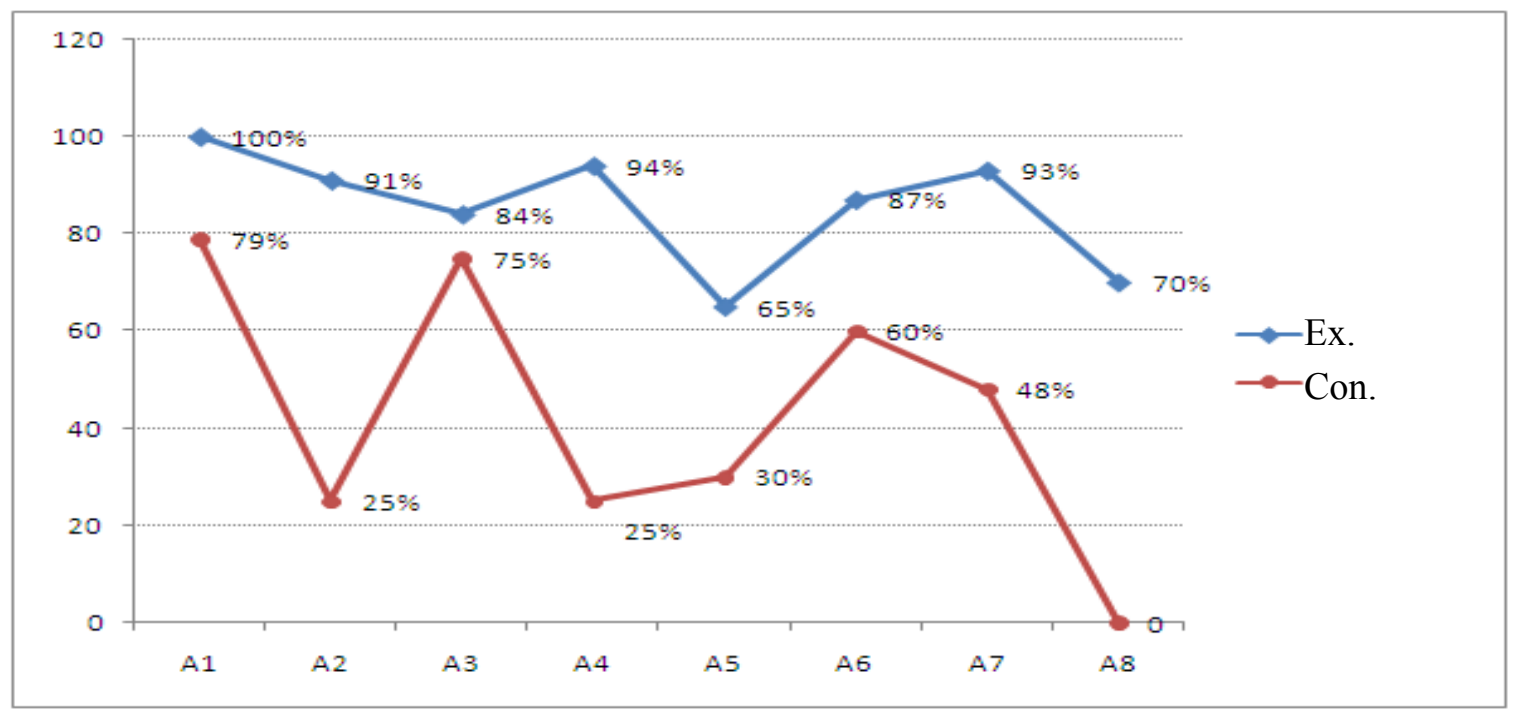

Figure 3. Comparison of each aspect of multiple intelligence used between the experimental and control groups shown by a line figure

A1 = Linguistic Intelligence

A2 $=$ Logical/Mathematical Intelligence

A3 $=$ Visual/Spatial Intelligence

A4 = Bodily Kinesthetic Intelligence

A5 $=$ Musical Intelligence

A6= Interpersonal Intelligence

A7 = Intrapersonal Intelligence

A8 =Naturalist Intelligence

\section{Discussion of Findings}

The results of this study can possibly be explained as follows:

1) By using the program of cross- curriculum thematic instruction based on multiple intelligence theory, the teacher-students of the experimental groups could experience greater precision in language performance than those of the control groups; their own thinking ability and potential intelligence enable them to continuously link the meaning of successive texts they read through. This helped them much better in developing their language performance at different points of learning after the experiment. In terms of interpretation and translation of different types of texts from mother tongue to foreign language and vice versa, the development in their language performance was significantly better in both spoken and written forms.

2) The teacher students in the experimental groups had more experience than those in the control groups in 
practicing their language skills in more diverse social contexts and thus had to encounter more diverse text types or genres, schematic structures as well as linguistic features in both spoken and written language through different aspects of multiple intelligence activities in more motivating learning settings.

3) Even though the teacher-students in the control groups had independently studied and experienced both spoken and written language through active learning program of student-centered approach, their experience in broader linkage of knowledge network was less than that of the teacher-students of the experimental groups who enjoyed sharing their intelligence-based learning activity programs both within and outside the class among friends with different resources, such as display boards, different topic presentations, discussions , debates, etc

4) Teacher-students in the experimental groups could better evaluate their strengths and weaknesses in their chosen activities by covering all aspects of intelligences than those in the control groups who emphasized only on completing the skills of language use on one topic at a time. The motivation to learn through their potential intelligences across the curriculum, as well as the teachers-students' achievement recognition program of the learning process, could enable the experimental groups to develop their language skills more progressively than those in the control groups with the same amount of learning time of the experiment.

\section{Conclusions and Recommendations}

In comparison to the pretest stages which were not significantly different between the experimental and control groups, the results of this study show that undergraduate -students taught through the program of cross-curricular thematic instruction based on multiple intelligence theory can improve their English performance in listening-speaking, reading and writing significantly much better than those in the control group taught through conventional instruction. The teacher-students of the experimental group expressed significantly higher positive opinion than those of the control group on the learning programs they received. Besides, the teacher-students of the experimental group, taught through the two instructional programs, based on multiple intelligences, could gain more experience across curriculum with different selected thematic texts and successfully improve their motivation to learn and English performance, which are relevant to the stated hypothesis.

In view of the positive results of the teacher-students of the experimental groups taught through the instructional program of cross-curricular thematic instructional based on multiple intelligence theory, the curriculum for prospective teachers of the School of Education, especially the syllabus of English courses, should be continuously integrated, every year, with other subject areas so as to enable them develop and master their language performance in more diverse situations and thus, in turn, effectively benefit their prospective students after graduation. Integration with other techniques of English teaching methodology and learning styles and techniques can be done while planning the curriculum. Mapping techniques can be useful for planning the relevant content areas and implementing those in effective program of learning based on activities covering multiple intelligences. Most importantly, regular counseling and assistance of the teachers to scaffold the teacher- students in using language appropriately and in preparation of proper thematic materials and other learning resources will be very helpful in making better programs for teaching of English teachers in a foreign language.

\section{Acknowledgements}

The author gratefully acknowledges Professor Nonglak Wiratchai and Associate Professor Chusri Wongchurattana for statistical advice and Miss Acharaphan Kansuya for her assistance in data analysis through computer program process.

\section{References}

BaŞ, G., \& Beyhan, Ò. (2010). Effects of Multiple Intelligences Supported Project based on Students' Achievement Levels and Attitudes towards English Lesson. International Electronic Journal of Elementary Education, 2(3), 365-384.

Campbell, L., Campbell, B., \& Dickinson, D. (2004). Teaching and Learning through Multiple Intelligences (3rd Ed.). New York: Pearson Education, Inc.

Chen, S. F. (2005). Cooperative Learning, Multiple Intelligence and Proficiency: Application in College English Language Teaching and Learning. (Doctoral dissertation). Australia Catholic University, Australia.

Christie, F. (1994). The place of genres in teaching social literacy. In Alison B. Littlefair (Ed.), Literacy for life. United Kingdom Reading Association.

Christie, F. (2005). Language Education in the Primary Years. Sydney: University of NSW Press. 
Cognition and Technology Group at Vanderbilt. (1997). The Jasper project: Lessons in curriculum, instruction, assessment and professional development. Mahwah, NJ: LEA.

Drake, S. M. (2001). Castles, Kings and Standards. Educational Leadership, 59, 38-42.

Drury, A. (1994). Restructuring the school: An assessment of the effect of an interdisciplinary curriculum on student achievement. (Doctoral dissertation). Central Michigan University, United States-Michigan. Retrieved March 21, 2009, from Dissertations \& Theses: Full Text database. (Publication No.AAT 1358145).

Gardner, H. (1983). Frame of Mind: The Theory of Multiple Intelligences. New York: Basic Books.

Goodman, K. S. (1986). What's whole in whole language? Hong Kong: Scholastic.

Goodman, K. S. (1993). Multiple Intelligences: The Theory in Practice. New York: Basic books.

Halliday, M. A. K. (1978). Language as social semiotic: The social interpretation of language and meaning. London: Edward Arnold.

Kovalik, S. (1994). Integrated Thematic Instruction: The Model. Kent.WA: Susan Kovalik \& Associates.

Lee, M. (2000). Spark up the American revolution with math, science, and more. The Social Studies, 159-164.

National Testing Bureau, Ministry of Education. (2010). The report of national test for basic education level (O-NET) 2010 Academic year. Retrieved April 5, 2010, from http://www.niets.or.th

Office of the Education Council. (2008). Education in Thailand 2007. Bangkok.

Sebeok, T. A. (1991). A sign is just a sign. Bloomington: Indiana University Press.

Starnes, B. A. (2007). Thought on teaching; Twisted NCLB or twisting NCLB. Phi Delta Kappan, 84(4), 314-315.

Stephens, P. J. (2007). Integrated thematic instruction connects, disjointed and incoherent curriculums. Published Literature Review, Nova: Southeastern University, Florida.

Summerville, R. H. (1984). A program for the integration of reading and composition into social studies curriculum in a selected junior high school. (Doctoral dissertation). The University of Alabama, United States, Alabama. Retrieved February 20, 2009, from Dissertation \& Theses: Full Text database. (Publication No. AAT 8513578)

Vaiou, A. (2010). Multiple Intelligences within the Cross Curricular Approach. Research Papers in Language Teaching and Learning, 1(1), 36-37.

Walker, R. F. (1994). Nature of Language. A Paper for CLE Workshop at Nakhonprathom Province, Thailand. Mimeographed.

\section{Copyrights}

Copyright for this article is retained by the author(s), with first publication rights granted to the journal.

This is an open-access article distributed under the terms and conditions of the Creative Commons Attribution license (http://creativecommons.org/licenses/by/3.0/). 